\title{
Etidronate from Medicine to Endodontics: effects of different irrigation regimes on root dentin roughness
}

Talita TARTARI ${ }^{1}$, Anivaldo Pereira DUARTE JUNIOR², José Otávio Carrera SILVA JÚNIOR ${ }^{2}$, Eliza Burlamaqui KLAUTAU $^{3}$, Mario Honorato SILVA E SOUZA JUNIOR ${ }^{4}$, Patrícia de Almeida Rodrigues SILVA E SOUZA ${ }^{1}$

\footnotetext{
1- Department of Endodontics, Dental School, Federal University of Pará, Belém, PA, Brazil.

2- Department of Pharmaceutical Sciences, Pharmacy School, Federal University of Pará, Belém, PA, Brazil.

3- Department of Dental Materials, Dental School, Federal University of Pará, Belém, PA, Brazil.

4- Department of Restorative Dentistry, Dental School, Federal University of Pará, Belém, PA, Brazil.
}

Corresponding address: Mario Honorato Silva e Souza Jr. - Faculdade de Odontologia - UFPA - Departamento de Dentística Restauradora - R. Augusto Corrêa, 1, Guamá - 66075-110 - Belém - PA - Brasil - Phone: +55 9132017563 - Fax: +55 9132017563 - e-mail: mario-honorato@hotmail.com

Submitted: March 15, 2013 - Modification: May 6, 2013 - Accepted: June 17, 2013

\section{ABSTRACT}

\begin{abstract}
$A^{n}$ $n$ increase in dentin roughness, associated with surface composition, contributes to bacterial adherence in recontaminations. Surface roughness is also important for micromechanical interlocking of dental materials to dentin, and understanding the characteristics of the surface is essential to obtain the adhesion of root canal sealers that have different physico-chemical characteristics. Objectives: To evaluate the effects of sodium hypochlorite $(\mathrm{NaOCl})$, ethylenediaminetetraacetic (EDTA), etidronic (HEBP), and citric acid (CA) associated with different irrigation regimens on root dentin roughness. Material and Methods: Forty-five root halves of anterior teeth were used. The root parts were sectioned in thirds, embedded in acrylic resin and polished to a standard surface roughness. Initially, the samples of each third were randomly assigned into 3 groups and treated as follows: G1 - saline solution (control); G2 - 5\% NaOCl+18\% HEBP mixed in equal parts; and G3 $-2.5 \% \mathrm{NaOCl}$. After initial measuments, the G3 samples were distributed into subgroups G4, G5 and G6, which were subjected to 17\% EDTA, 10\% CA and 9\% HEBP, respectively. Following the new measuments, these groups received a final flush with $2.5 \% \mathrm{NaOCl}$, producing G7, G8 and G9. The dentin surface roughness (Ra) was determined before and after treatments using a profilometer. The Wilcoxon test $(\alpha<0.05)$ was used to compare the values before and after treatments, and the Friedman test $(\alpha<0.05)$ to detect any differences among root thirds. Results: (i) NaOCl did not affect the surface roughness; (ii) there was a significant increase in roughness after the use of chelating agents $(P<0.01)$; and (iii) only the G3 group showed a difference in surface roughness between apical third and other thirds of the teeth $(P<0.0043)$. Conclusion: Only the irrigation regimens that used chelating agents altered the roughness of root dentin.
\end{abstract}

Keywords: Chelating agents. Dentin. Etidronic acid. Root canal irrigants. Surface properties.

\section{INTRODUCTION}

Adhesion involves interactions at the interface between materials and depends of several factors as cleanliness, composition, and roughness of adherent surface. Mechanical bonding is the most effective means of creating strong joints. In this type of adhesion, the material penetrates into the adherent, becoming mechanically interlocked at some level. To attain effective adhesive bonding, it is important that the adherent have a clean and rough surface ${ }^{18}$. Irrigating solutions used in Endodontics clean the dentin surface, and may interfere with the chemical structure of dentin, changing the calcium/ phosphorus $(\mathrm{Ca} / \mathrm{P})$ ratio of the surface ${ }^{11}$. These alterations can increase the surface roughness ${ }^{3,12}$, which may affect the sealing ability and adhesion of dental materials - such as resin-based cements and root canal sealers - to dentin ${ }^{16,24}$ and alter the nature of adhesion and the adhesion strength of 
various bacteria ${ }^{14,23}$.

Sodium hypochlorite solutions $(\mathrm{NaOCl})$ are the most common irrigating agents used in biomechanical preparation based on their excellent microbicidal activity and tissue-dissolving capabilities ${ }^{19}$. However, despite these properties, this solution only removes the organic structure of the smear layer produced during mechanical instrumentation ${ }^{7}$, and combining it with chelating agents is necessary to remove the inorganic phase of this layer ${ }^{13}$. Various chelating agents can be used for this purpose, such as ethylenediaminetetraacetic acid (EDTA), citric acid (CA), MTAD (mixture of doxycycline, citric acid and Tween 80), and chitosan ${ }^{13,22,27}$. Recently, etidronate (HEBP), a substance that prevents bone resorption has been used in medicine for patients suffering from osteoporosis or Paget's disease, and was suggested as substitute for traditional chelators due to fewer effects observed on dentin structure ${ }^{6}$. It is considered the unique chelator that can be mixed with $\mathrm{NaOCl}$ without interfering with its antimicrobial property ${ }^{30}$.

However, chelating solutions also remove calcium ions from the dentin surface, exposing the collagen matrix, which may contribute to bacterial adherence in recontaminations, as with Enterococcus faecalis ${ }^{14,15}$. The use of $\mathrm{NaOCl}$ solutions has been suggested as a strategy to remove this exposed collagen matrix in a process called deproteination ${ }^{4,14}$, which restores to the surface characteristics of untreated dentin?

The importance of roughness studies is supported due to the strong relationship between surface topography and its influence on dentin wettability, a property that directly influences the bonding of the dental materials ${ }^{8}$ and microorganism adhesion ${ }^{25}$. The increase in roughness could be potentiated by the combination of the irrigation solutions and, to date, there have been no studies evaluating the effect of HEBP and different irrigation regimens on the roughness of root canal dentin. Therefore, the purpose of this in vitro study was to evaluate the effects of $\mathrm{NaOCl}$, EDTA, HEBP and CA associated with different irrigation regimens on root dentin roughness.

\section{MATERIAL AND METHODS}

This study was reviewed and approved by the Ethics Committee on Human Research.

\section{Solutions}

Solutions of $2.5 \%(\mathrm{wt} / \mathrm{vol})$ and $5 \% \mathrm{NaOCl}, 10 \%$ CA (Sigma-Aldrich, St Louis, Missouri, USA), 9 and 18\% HEBP (Zschimmer \& Schwarz Mohsdorf GmbH \& Co KG, Burgstädt, SN, Germany) were prepared using pure chemicals dissolved in deionized water. The $17 \%$ EDTA solution (Sigma Aldrich) was prepared as previously described in other study ${ }^{21}$.

All solutions were stored at $5^{\circ} \mathrm{C}$ in airtight dark containers between experiments; prior to being used, the solutions were removed from the refrigerator and stored for $60 \mathrm{~min}$ at room temperature. A fresh 1:1 mixture of $5 \% \mathrm{NaOCl}$ and $18 \%$ HEBP was prepared immediately before the experiments, producing a solution that contained $2.5 \% \mathrm{NaOCl}$ and $9 \% \mathrm{HEBP}^{30}$.

\section{Teeth selection and preparation}

Forty-five root halves of anterior teeth were used. The sample size was determined after a pilot study. Remnants of debris and soft tissue on the tooth surfaces were removed, and all teeth stored in $0.1 \%$ thymol at $9^{\circ} \mathrm{C}$ until use.

Teeth with caries, cracks, and root dilacerations were excluded. Tooth crowns were removed at the cement-enamel junction using a low-speed diamond disk (KG Sorensen Ind. e Com., Barueri, SP, Brazil) with water cooling. The canals were explored with a size $15 \mathrm{~K}$-type file (Dentsply Maillefer, Ballaigues, Switzerland) until the tip of the instrument was adjusted to the apical foramen. At this point, another sectioning was performed to standardize the root apical limit and ensure that only the canal dentin was analyzed. Subsequently, each root was sectioned longitudinally in the buccolingual direction to expose the entire canal extension, and the pulp tissue was removed. The tooth halves thirds were transversely marked with the aid of a digital caliper PD-150 (Vonder, Curitiba, PR, Brazil), and then the halves were horizontally sectioned into apical, middle and cervical thirds. Each segment was identified and horizontally mounted in autopolymerizing acrylic resin (Dentbras Ind. Com. Imp. Exp. Prod. Odont. Ltda, Pirassununga, SP, Brazil) with the canal dentin exposed. The specimens were wet polished on a circular grinding machine with a series of ascending grades $(400,600,1200$, and 2000) of silicon carbide abrasive papers (3M do Brasil Ltda., Sumaré, SP, Brazil) under water coolant to achieve a standard surface roughness. Then, the samples were thoroughly washed and sonicated in distilled water to remove residual particles.

The surface roughness of each sample was determined in Ra (arithmetic average roughness $\mu \mathrm{m})$ with a portable digital roughness tester S] 301 (Mitutoyo, Tokyo, Japan) within a pre-established cut-off (distance traveled in each reading) of 0.8 $\mathrm{mm}$. Three tracings of different locations on the root canal lumen dentin were made. Specimens with similar surface roughness were included in the study; the other samples were again subjected to polishing until they reached the roughness standard mean (0.10-0.14 Ra) determined by the pilot test.

The 45 specimens of each third were randomly divided into groups as shown in Figure 1. 
The solution treatments were carried out in three stages. In stage 1 , the specimens were immersed in irrigating solutions for 30 minutes to simulate the biomechanical preparation. In stage 2 , the inorganic phase of the smear layer was removed through the application of chelating agents, and in step 3, deproteination was performed with the use of $2.5 \%$ $\mathrm{NaOCl}$ solution for $3 \mathrm{~min}$.

The specimens were immersed in $40 \mathrm{~mL}$ of tested solutions and ultrasonicated. The irrigation solutions were renewed every $5 \mathrm{~min}$ to ensure their chemical effectiveness. After each step, the specimens were washed for $1 \mathrm{~min}$ with distilled water in an ultrasonic tub to avoid residual effects from the solutions.

The measurements were performed after each stage in the same manner as the initial measurements, and the roughness values were recorded.

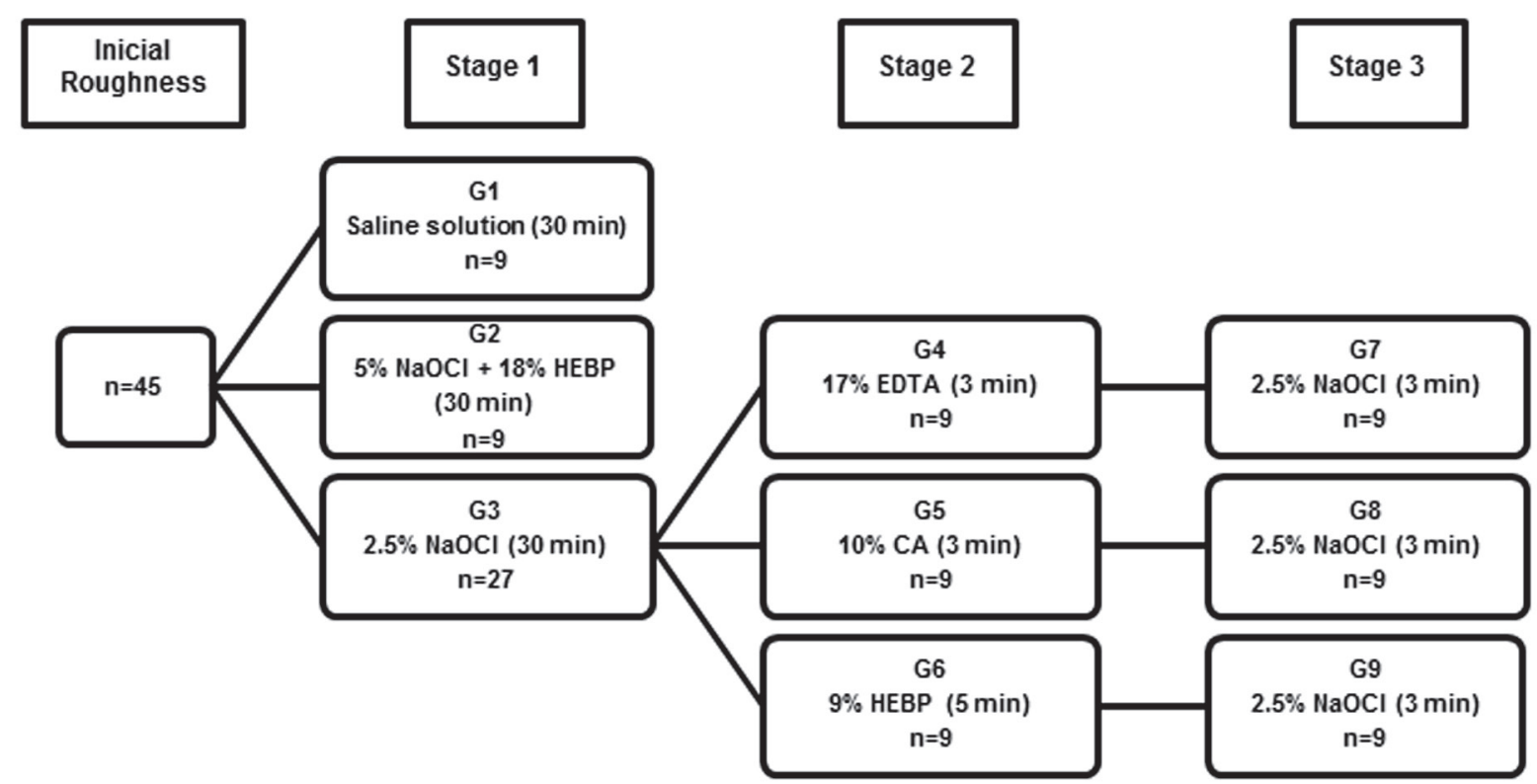

Figure 1- Experimental groups

Table 1- Median (Med) and interquartile range (IQR) and $P$ values (Wilcoxon test) for roughness analysis in the cervical third before (TO) and after (T1) the application of the irrigation regimens

\begin{tabular}{|c|c|c|c|}
\hline \multirow[t]{2}{*}{ Groups } & \multicolumn{3}{|c|}{ Cervical Third } \\
\hline & TO & T1 & $P$ value \\
\hline & Med $\pm I Q R$ & Med $\pm I Q R$ & (Wilcoxon) \\
\hline G1 - Saline & $0.11 \pm 0.03$ & $0.11 \pm 0.02$ & 0.48 \\
\hline $\begin{array}{c}\mathrm{G} 2-\text { Mixture } 5 \% \mathrm{NaOCl} \text { and } \\
18 \% \text { HEBP (30 min) }\end{array}$ & $0.11 \pm 0.02$ & $1.27 \pm 1.67$ & $<0.01$ \\
\hline $\mathrm{G} 3-2.5 \% \mathrm{NaOCl}$ (30 min) & $0.12 \pm 0.03$ & $0.13 \pm 0.02$ & 0.35 \\
\hline $\begin{array}{c}\mathrm{G} 4-2.5 \% \mathrm{NaOCl}(30 \mathrm{~min}) \\
\quad+17 \% \text { EDTA }(3 \mathrm{~min})\end{array}$ & $0.12 \pm 0.03$ & $0.51 \pm 0.29$ & $<0.01$ \\
\hline $\begin{aligned} \mathrm{G} 5 & -2.5 \% \mathrm{NaOCl}(30 \mathrm{~min}) \\
& +10 \% \mathrm{CA}(3 \mathrm{~min})\end{aligned}$ & $0.10 \pm 0.03$ & $1.34 \pm 0.61$ & $<0.01$ \\
\hline $\begin{aligned} \mathrm{G} 6 & -2.5 \% \mathrm{NaOCl}(30 \mathrm{~min}) \\
& +9 \% \mathrm{HEBP}(5 \mathrm{~min})\end{aligned}$ & $0.11 \pm 0.02$ & $0.23 \pm 0.09$ & $<0.01$ \\
\hline $\begin{array}{c}\mathrm{G} 7-2.5 \% \mathrm{NaOCl}(30 \mathrm{~min}) \\
+17 \% \text { EDTA }(3 \mathrm{~min})+2.5 \% \\
\mathrm{NaOCl}(3 \mathrm{~min})\end{array}$ & $0.12 \pm 0.03$ & $0.40 \pm 0.36$ & $<0.01$ \\
\hline $\begin{array}{c}\mathrm{G} 8-2.5 \% \mathrm{NaOCl}(30 \mathrm{~min}) \\
+10 \% \mathrm{CA}(3 \mathrm{~min})+2.5 \% \\
\mathrm{NaOCl}(3 \mathrm{~min})\end{array}$ & $0.10 \pm 0.03$ & $1.49 \pm 0.03$ & $<0.01$ \\
\hline $\begin{array}{c}\mathrm{G} 9-2.5 \% \mathrm{NaOCl}(30 \mathrm{~min}) \\
+9 \% \mathrm{HEBP}(5 \mathrm{~min})+2.5 \% \\
\mathrm{NaOCl}(3 \mathrm{~min})\end{array}$ & $0.11 \pm 0.02$ & $0.21 \pm 0.11$ & $<0.01$ \\
\hline
\end{tabular}




\section{Statistical analysis}

Twenty-seven specimens of each root third were subjected to $\mathrm{NaOCl}$ and then distributed according to the irrigation regimens used. To avoid false- positive inflation, the roughness values of only 9 specimens were randomly selected for statistical analysis of the G3.

The sample exhibited normal distribution and

Table 2- Median (Med) and interquartile range (IQR) and $P$ values (Wilcoxon test) for roughness analysis in the middle third before (T0) and after (T1) the application of the irrigation regimens

\begin{tabular}{|c|c|c|c|}
\hline \multirow[t]{3}{*}{ Groups } & \multicolumn{3}{|c|}{ Middle Third } \\
\hline & TO & T1 & $P$ value \\
\hline & Med $\pm I Q R$ & Med $\pm I Q R$ & (Wilcoxon) \\
\hline G1 - Saline & $0.11 \pm 0.02$ & $0.11 \pm 0.03$ & 0.86 \\
\hline $\begin{array}{c}\text { G2 - Mixture } 5 \% \mathrm{NaOCl} \text { and } \\
18 \% \operatorname{HEBP}(30 \mathrm{~min})\end{array}$ & $0.11 \pm 0.02$ & $1.25 \pm 0.57$ & $<0.01$ \\
\hline $\mathrm{G} 3-2.5 \% \mathrm{NaOCl}$ (30 min) & $0.12 \pm 0.02$ & $0.12 \pm 0.02$ & 0.26 \\
\hline $\begin{aligned} \mathrm{G} 4 & -2.5 \% \mathrm{NaOCl}(30 \mathrm{~min}) \\
& +17 \% \text { EDTA }(3 \mathrm{~min})\end{aligned}$ & $0.10 \pm 0.02$ & $0.48 \pm 0.10$ & $<0.01$ \\
\hline $\begin{aligned} \mathrm{G} 5 & -2.5 \% \mathrm{NaOCl}(30 \mathrm{~min}) \\
& +10 \% \mathrm{CA}(3 \mathrm{~min})\end{aligned}$ & $0.10 \pm 0.03$ & $1.00 \pm 0.89$ & $<0.01$ \\
\hline $\begin{array}{c}\mathrm{G} 6-2.5 \% \mathrm{NaOCl}(30 \mathrm{~min}) \\
+9 \% \mathrm{HEBP}(5 \mathrm{~min})\end{array}$ & $0.11 \pm 0.03$ & $0.22 \pm 0.08$ & $<0.01$ \\
\hline $\begin{array}{l}\mathrm{G} 7-2.5 \% \mathrm{NaOCl}(30 \mathrm{~min}) \\
+17 \% \mathrm{EDTA}(3 \mathrm{~min})+2.5 \% \\
\mathrm{NaOCl}(3 \mathrm{~min})\end{array}$ & $0.10 \pm 0.02$ & $0.45 \pm 0.11$ & $<0.01$ \\
\hline $\begin{array}{c}\mathrm{G} 8-2.5 \% \mathrm{NaOCl}(30 \mathrm{~min}) \\
+10 \% \mathrm{CA}(3 \mathrm{~min})+2.5 \% \\
\mathrm{NaOCl}(3 \mathrm{~min})\end{array}$ & $0.10 \pm 0.03$ & $1.29 \pm 0.43$ & $<0.01$ \\
\hline $\begin{array}{c}\mathrm{G} 9-2.5 \% \mathrm{NaOCl}(30 \mathrm{~min}) \\
+9 \% \mathrm{HEBP}(5 \mathrm{~min})+2.5 \% \\
\mathrm{NaOCl}(3 \mathrm{~min})\end{array}$ & $0.11 \pm 0.03$ & $0.24 \pm 0.09$ & $<0.01$ \\
\hline
\end{tabular}

Table 3- Median (Med) and interquartile range (IQR) and $P$ values (Wilcoxon test) for roughness analysis in the apical third before (T0) and after (T1) the application of the irrigation regimens

\begin{tabular}{|c|c|c|c|}
\hline \multirow[t]{2}{*}{ Groups } & \multicolumn{3}{|c|}{ Apical Third } \\
\hline & TO & T1 & $P$ value \\
\hline & Med $\pm I Q R$ & Med $\pm I Q R$ & (Wilcoxon) \\
\hline G1 - Saline & $0.10 \pm 0.02$ & $0.10 \pm 0.02$ & 0.50 \\
\hline $\begin{array}{c}\mathrm{G} 2-\text { Mixture } 5 \% \mathrm{NaOCl} \text { and } \\
18 \% \mathrm{HEBP}(30 \mathrm{~min})\end{array}$ & $0.11 \pm 0.02$ & $0.25 \pm 0.19$ & $<0.01$ \\
\hline $\mathrm{G} 3-2.5 \% \mathrm{NaOCl}$ (30 min) & $0.11 \pm 0.01$ & $0.13 \pm 0.02$ & 0.26 \\
\hline $\begin{aligned} \mathrm{G} 4 & -2.5 \% \mathrm{NaOCl}(30 \mathrm{~min}) \\
& +17 \% \text { EDTA }(3 \mathrm{~min})\end{aligned}$ & $0.11 \pm 0.01$ & $0.51 \pm 0.25$ & $<0.01$ \\
\hline $\begin{aligned} \mathrm{G} 5 & -2.5 \% \mathrm{NaOCl}(30 \mathrm{~min}) \\
& +10 \% \mathrm{CA}(3 \mathrm{~min})\end{aligned}$ & $0.11 \pm 0.02$ & $1.07 \pm 0.50$ & $<0.01$ \\
\hline $\begin{aligned} \mathrm{G} 6 & -2.5 \% \mathrm{NaOCl}(30 \mathrm{~min}) \\
& +9 \% \mathrm{HEBP}(5 \mathrm{~min})\end{aligned}$ & $0.11 \pm 0.01$ & $0.22 \pm 0.05$ & $<0.01$ \\
\hline $\begin{array}{c}\mathrm{G} 7-2.5 \% \mathrm{NaOCl}(30 \mathrm{~min}) \\
+17 \% \text { EDTA }(3 \mathrm{~min})+2.5 \% \\
\mathrm{NaOCl}(3 \mathrm{~min})\end{array}$ & $0.11 \pm 0.01$ & $0.57 \pm 0.44$ & $<0.01$ \\
\hline $\begin{array}{c}\mathrm{G} 8-2.5 \% \mathrm{NaOCl}(30 \mathrm{~min}) \\
+10 \% \mathrm{CA}(3 \mathrm{~min})+2.5 \% \\
\mathrm{NaOCl}(3 \mathrm{~min})\end{array}$ & $0.11 \pm 0.02$ & $1.11 \pm 0.63$ & $<0.01$ \\
\hline $\begin{array}{c}\mathrm{G} 9-2.5 \% \mathrm{NaOCl}(30 \mathrm{~min}) \\
+9 \% \mathrm{HEBP}(5 \mathrm{~min})+2.5 \% \\
\mathrm{NaOCl}(3 \mathrm{~min})\end{array}$ & $0.11 \pm 0.01$ & $0.24 \pm 0.09$ & $<0.01$ \\
\hline
\end{tabular}


Table 4- The $P$ values (Friedman test) of the roughnesses before (T0) and after (T1) the same treatment on different thirds

\begin{tabular}{|c|c|c|}
\hline Groups & $\begin{array}{c}\text { CT X MT } \\
\text { CT X AT } \\
\text { MT X AT } \\
\text { P value in TO (Friedman) }\end{array}$ & $\begin{array}{c}\text { CT X MT } \\
\text { CT X AT } \\
\text { MT X AT } \\
\text { P value in T1 (Friedman) }\end{array}$ \\
\hline G1 - Saline & 0.69 & 0.77 \\
\hline $\begin{array}{c}\mathrm{G} 2 \text { - Mixture } 5 \% \mathrm{NaOCl} \text { and } 18 \% \mathrm{HEBP}(30 \\
\mathrm{min})\end{array}$ & 0.82 & $0.0043^{*}$ \\
\hline $\mathrm{G} 3-2.5 \% \mathrm{NaOCl}(30 \mathrm{~min})$ & 0.97 & 0.55 \\
\hline $\mathrm{G} 4-2.5 \% \mathrm{NaOCl}(30 \mathrm{~min})+17 \%$ EDTA $(3 \mathrm{~min})$ & 0.36 & 0.45 \\
\hline $\mathrm{G} 5-2.5 \% \mathrm{NaOCl}(30 \mathrm{~min})+10 \% \mathrm{CA}(3 \mathrm{~min})$ & 0.92 & 0.89 \\
\hline $\mathrm{G} 6-2.5 \% \mathrm{NaOCl}(30 \mathrm{~min})+9 \% \mathrm{HEBP}(5 \mathrm{~min})$ & 0.42 & 0.92 \\
\hline $\begin{array}{c}\mathrm{G} 7-2.5 \% \mathrm{NaOCl}(30 \mathrm{~min})+17 \% \text { EDTA }(3 \mathrm{~min}) \\
+2.5 \% \mathrm{NaOCl}(3 \mathrm{~min})\end{array}$ & 0.36 & 0.69 \\
\hline $\begin{array}{c}\mathrm{G} 8-2.5 \% \mathrm{NaOCl}(30 \mathrm{~min})+10 \% \mathrm{CA}(3 \mathrm{~min})+ \\
2.5 \% \mathrm{NaOCl}(3 \mathrm{~min})\end{array}$ & 0.92 & 0.23 \\
\hline $\begin{aligned} \mathrm{G} 9-2.5 \% \mathrm{NaOCl}(30 \mathrm{~min})+9 \% \mathrm{HEBP}(5 \mathrm{~min}) \\
+2.5 \% \mathrm{NaOCl}(3 \mathrm{~min})\end{aligned}$ & 0.42 & 0.89 \\
\hline
\end{tabular}

CT=cervical third; MT=middle third; AT=apical third; * $\mathrm{P}=0.0043$ : CT $\times$ MT P=not significant; CT $x$ AT P<0.05; and MT x AT $\mathrm{P}<0.05$

unequal variances. The nonparametric Wilcoxon test $(\alpha<0.05)$ was used to compare the dentin surface roughnesses before and after treatments, and the Friedman test $(a<0.05)$ was used to detect differences among the root thirds.

\section{RESULTS}

The median and interquartile range of roughness values of root canal dentin before and after treatment with irrigation regimens in cervical, middle, and apical thirds are summarized in Tables 1 , 2 and 3, respectively. A significant increase in dentin roughness was observed following the treatment with the different irrigation regimens, except when saline (G1) or $\mathrm{NaOCl}$ (G3) were used alone.

The data for initial roughness revealed no statistically significant difference among the different thirds (Table 4). After treatments, the different thirds behaved the same way, except in G2 in which the apical third had a lower increase in surface roughness than did the other thirds $(P=0.0043)$.

\section{DISCUSSION}

The irrigation solutions might influence the physicochemical properties of human root canal dentin, including microhardness, permeability, solubility, wettability and roughness ${ }^{3,12}$. In Endodontics, an increase in surface roughness could be clinically beneficial because it may enhance the micromechanical bonding of root canal sealers, which requires irregularities on the surface of the adherent for penetration ${ }^{3,12}$. However, too much roughness can facilitate bacterial adhesion, which might lead to plaque formation 23,25.

In the present study, $\mathrm{NaOCl}$ treatment did not modify the roughness of the dentin surface when used before or after the chelating agents, consistent with previous findings that $\mathrm{NaOCl}$ does not cause decalcification ${ }^{17}$ or changes in dentin wettability ${ }^{2,26}$, a factor that has been correlated with dentin roughness ${ }^{8,12}$. However, these results are in contrast to those of other studies ${ }^{1,12,20}$, most likely due to the standardization of the initial polishing used here; this procedure was not reported in the other studies. Initial roughness standardization is recommended in studies of chemical conditioning because it offers a controlled reference point for the correct and unambiguous assessment of the morphological effects induced by subsequent chemical treatments ${ }^{9}$.

A major change in surface topography occurs after the use of chelating agents. The regimens that employed CA (G5 and G8) and HEBP mixed with $\mathrm{NaOCl}$ (G2) demonstrated greater increases in roughness values than did other groups. The strong activity of CA is most likely due to its greater capacity for demineralization ${ }^{5}$ that, in addition to removing the smear layer, can also cause extensive demineralization in dentinal tubules and peritubular dentin ${ }^{10}$. When mixed, the HEBP causes some reduction in the activity of $\mathrm{NaOCl}$ after $1 \mathrm{~h}$, but the two substances remain active in fresh mixture ${ }^{30}$. The results observed in $\mathrm{G} 2$ are most likely due to the ability of $\mathrm{NaOCl}$ to create deproteination canals in the dentin 7 , which may increase the area of action available for HEBP. Associated with this factor, the longer use of this weak chelating agent for $30 \mathrm{~min}$ also may have potentiated its effect. 
The smallest changes in surface roughness after the use of a chelating agent were observed in regimens that employed $9 \%$ HEBP for 5 min after $\mathrm{NaOCl}$ treatment (G6 and G9). These findings confirm that HEBP is a weak chelating agent that attacks less dentin surface than other commonly used chelators, such as EDTA, but the HEBP solutions need 300 seconds to completely remove the smear layer ${ }^{6}$.

In terms of the behavior of different root thirds in each of the irrigation regimens, it was observed that, despite the heterogeneous structure of these regions ${ }^{17,28,29}$, they exhibit similar behaviors in response to direct contact between the irrigation agent and the root surface (Table 4). One exception was the apical third in G2, possibly because the greater percentage of sclerotic dentin in this area $17,28,29$ reduced the number of deproteination canals created by $\mathrm{NaOCl}$, decreasing the area of action available for HEBP.

The results of this study showed the effects of direct contact from different irrigation regimens using different auxiliary chemical substances on dentin surface roughness. However, these results cannot be extrapolated to clinical practice, because it is difficult to introduce irrigation solution to the apical region, which, associated to the use of endodontic instruments, may change these values. However, the analysis of the behavior of different root thirds into direct contact with the irrigating solutions is relevant to assess if, besides the difficulty of the irrigators to reach the apex, the dentin composition also influences the increase in roughness. It was possible to observe that only the irrigation regimens that employed chelating solutions increased the surface roughness and the use of $\mathrm{NaOCl}$ before the chelating agents or as a final flush did not modify the dentin roughness. Further studies should be performed to evaluate not only the effect of different irrigation regimes on the dentin structure but also the effect of these protocols on the adhesion of root canal sealers and bacteria in recontaminations.

\section{CONCLUSIONS}

The findings of this study indicated that only the irrigation regimens that used chelating agents were capable of increasing the roughness of root canal dentin.

\section{ACKNOWLEDGMENTS}

This study was supported in part by CAPES Coordination of Higher Education and Graduate Training - and by CNPq - National Council for Scientific and Technological Development.

\section{REFERENCES}

1- Ari H, Erdemir A, Belli S. Evaluation of the effect of endodontic irrigation solutions on the microhardness and the roughness of root canal dentin. J Endod. 2004;30:792-5.

2- Attal JP, Asmussen E, Degrange M. Effects of surface treatment on the free surface energy of dentin. Dent Mater. 1994;10:259-64. 3- Ballal NV, Mala K, Bhat KS. Evaluation of the effect of maleic acid and ethylenediaminetetraacetic acid on the microhardness and surface roughness of human root canal dentin. J Endod. 2010;36:1385-8.

4- Baseggio W, Consolmagno EC, Carvalho FL, Ueda JK, Schmitt VL, Formighieri LA, et al. Effect of deproteinization and tubular occlusion on microtensile bond strength and marginal microleakage of resin composite restorations. J Appl Oral Sci. 2009;17:462-6. 5- De-Deus G, Paciornik S, Pinho Mauricio MH, Prioli R. Real-time atomic force microscopy of root dentine during demineralization when subjected to chelating agents. Int Endod J. 2006;39:683-92. 6- De-Deus G, Zehnder M, Reis C, Fidel S, Fidel RA, Galan J Jr, et al. Longitudinal co-site optical microscopy study on the chelating ability of etidronate and EDTA using a comparative single-tooth model. J Endod. 2008;34:71-5.

7- Di Renzo M, Ellis TH, Sacher E, Stangel I. A photoacoustic FTIRS study of the chemical modifications of human dentin surfaces: II. Deproteination. Biomaterials. 2001;22:793-7.

8- Eick JD, Johnson LN, Fromer JR, Good RJ, Neumann AW. Surface topography: its influence on wetting and adhesion in a dental adhesive system. J Dent Res. 1972;51:780-8.

9- El Feninat F, Elouatik S, Ellis TH, Sacher E, Stangel I. Quantitative assessment of surface roughness as measured by AFM: application to polished human dentin. Appl Surf Sci. 2001;183:205-15.

10- Haznedaroğlu F. Efficacy of various concentrations of citric acid at different $\mathrm{pH}$ values for smear layer removal. Oral Surg Oral Med Oral Pathol Oral Radiol Endod. 2003;96:340-4.

11- Hennequin M, Pajot J, Avignant D. Effects of different $\mathrm{pH}$ values of citric acid solutions on the calcium and phosphorus contents of human root dentin. J Endod. 1994;20:551-4.

12- Hu X, Ling J, Gao Y. Effects of irrigation solutions on dentin wettability and roughness. J Endod. 2010;36:1064-7.

13- Hülsmann M, Heckendorff $M$, Lennon A. Chelating agents in root canal treatment: mode of action and indications for their use. Int Endod J. 2003;36:810-30.

14- Kishen A, Sum CP, Mathew S, Lim CT. Influence of irrigation regimens on the adherence of Enterococcus faecalis to root canal dentin. J Endod. 2008;34:850-4.

15- Kowalski WJ, Kasper EL, Hatton JF, Murray BE, Nallapareddy SR, Gillespie MJ. Enterococcus faecalis adhesin, Ace, mediates attachment to particulate dentin. J Endod. 2006;32:634-7.

16- Lisboa DS, Santos SV, Griza S, Rodrigues JL, Faria-e-Silva AL. Dentin deproteinization effect on bond strength of self-adhesive resin cements. Braz Oral Res. 2013;27:73-5.

17- Lottanti S, Gautschi H, Sener B, Zehnder M. Effects of ethylenediaminetetraacetic, etidronic and peracetic acid irrigation on human root dentine and the smear layer. Int Endod J. 2009;42:335-43.

18- Marshall SJ, Bayne SC, Baier R, Tomsia AP, Marshall GW. A review of adhesion science. Dent Mater. 2010;26:e11-6.

19- Mohammadi Z. Sodium hypochlorite in endodontics: an update review. Int Dent J. 2008;58:329-41.

20- Patil CR, Uppin V. Effect of endodontic irrigating solutions on the microhardness and roughness of root canal dentin: an in vitro study. Indian J Dent Res. 2011;22:22-7.

21- Pérez-Heredia M, Ferrer-Luque CM, González-Rodríguez MP, Martín-Peinado FJ, González-López S. Decalcifying effect of $15 \%$ EDTA, $15 \%$ citric acid, $5 \%$ phosphoric acid and $2.5 \%$ sodium hypochlorite on root canal dentine. Int Endod J. 2008;41:418-23. 
22- Pimenta JA, Zaparolli D, Pécora JD, Cruz-Filho AM. Chitosan: effect of a new chelating agent on the microhardness of root dentin. Braz Dent J. 2012;23:212-7.

23- Quirynen M, Bollen CM. The influence of surface roughness and surface-free energy on supra- and subgingival plaque formation in man. A review of the literature. J Clin Periodontol. 1995;22:1-14. 24- Saleh IM, Ruyter IE, Haapasalo M, Ørstavik D. The effects of dentine pretreatment on the adhesion of root-canal sealers. Int Endod J. 2002;35:859-66.

25- Tang L, Pillai S, Revsbech NP, Schramm A, Bischoff C, Meyer $\mathrm{RL}$. Biofilm retention on surfaces with variable roughness and hydrophobicity. Biofouling. 2011;27:111-21.

26- Tani C, Manabe A, Itoh K, Hisamitsu H, Wakumoto S. Contact angle of dentin bonding agents on the dentin surface. Dent Mater J. $1996 ; 15: 39-44$.
27- Torabinejad M, Khademi AA, Babagoli J, Cho Y, Johnson WB, Bozhilov $K$, et al. A new solution for the removal of the smear layer. J Endod. 2003;29:170-5.

28- Vasiliadis L, Darling AI, Levers BGH. The amount and distribution of sclerotic human root dentine. Arch Oral Biol. $1983 ; 28: 645-9$.

29- Vasiliadis L, Darling AI, Levers BGH. The histology of sclerotic human root dentine. Arch Oral Biol. 1983;28:693-700.

30- Zehnder M, Schmidlin P, Sener B, Waltimo T. Chelation in root canal therapy reconsidered. J Endod. 2005;31:817-20. 